\title{
Investigation of the Cognition and Attitude of Junior High School Students on Energy Resources: The Case of Kai-Syuan Junior High School, I-Lan, Taiwan
}

\author{
Wang Chin-Tsan and Wu Kai-Ying
}

\begin{abstract}
In this study a questionnaire regarding background information, energy resource cognition and energy resource attitude of junior high school students would be investigated. Ninety-nine questionnaires were given to the students of Kai-syuan Junior High School, and $100 \%$ of those questionnaires were returned and determined suitable for analysis. They were analyzed by using descriptive statistics, the independent sample $T$ test, the paired sample $T$ test, and the Pearson Correlation Analysis for the following results:

Before teaching Energy Education, the students already had a reasonable level of energy resource cognition. After instruction in Energy Education, the energy resource cognition of the students significantly improved. Students were found to have intermediate level energy resource attitudes. Male and female energy resource attitudes were significantly different in the "life style" and "personal welfare" categories. Students with a greater energy cognition have better energy attitudes and understanding of energy conservation and are thus more like to proactive in this field. All findings in this study will be useful to improvement of energy education in high school.
\end{abstract}

Index Terms - Energy resource, cognition, attitudes, junior high school.

\section{INTRODUCTION}

Energy resources are the foundation of human civilization, having much to do with the safety and stability of a nation. As global warming worsens, the excessive emission of carbon dioxide and waste of energy resources have become a universal problem that all countries are eager to solve. However, when planning the development of carbon and energy reduction technology, most countries only focus on the techniques rather than any human-centered methods that are able to create social values. After the Industrial Revolution, energy resources were used to sustain the basic functions and foundational structures of civilization and to satisfy human need on both a physiological and psychological level. Facing the global issue of energy conservation and carbon reductions, traditional thinking has generally focused on increasing the transfer efficiency of energy resources, developing renewable energy resources in addition to developing carbon capture and sequestration techniques [1]-[4]. This study discusses the problem with the situation of energy education from the standpoint of Junior

Manuscript received May 1, 2014; revised July 30, 2014

C. T. Wang is with the Department of Mechanical and Electro-Mechanical Engineering, National I Lan University, I Lan 26047, Taiwan (e-mail: ctwang@niu.edu.tw).

K. Y. Wu is with Kai-Syuan Junior High School, I Lan 26047, Taiwan (e-mail: kaiingwu@yahoo.com.tw).
High School students. By using cognitive and behavioral science knowledge, the researchers tried to understand the concept and acceptance of energy conservation and carbon reduction among junior high school students. In the long run, changing the cognition and behavior of the younger population is actually a very inexpensive method of achieving social benefits [5]-[9]. Now, high school education in Taiwan has increased the importance placed on covering green energy. Although green energy is not a recent issue, the required background knowledge does not go beyond what is taught on the current junior high school Science curriculum and Chemistry and Technology curricula. It is hoped that the findings from this research will assist in the integration of the green curriculum and provide relevant supplementary measures. If students are introduced to a new green energy technology earlier in the school curriculum, it is beneficial for the development of green energy. The implementation of a series of energy education programs during the Junior High School years have been put into place to this aim. Therefore, it is necessary to build a relative framework on energy education so that it becomes rooted in the minds of the following generations.

\section{Methodology}

In this study, a self-made "Energy Education Promotion Manual" is used to implement cognitive teaching, while using the self-made "I-Lan County Junior High School Student Energy Resource Cognition and Attitude Questionnaire" as the instrument (Appendixed questionnaire). This section can be divided into four parts: Research Design, Instrument, Participants, and Procedure and Data Analysis.

\section{A. Research Design}

The primary method used in this research is the questionnaire method. Using the self-authored "Energy Resource Education Advancement Manual", cognitive education is administered. The students are questioned before and after administration. The effectiveness of energy resource education in improving energy resource cognition and attitude is then discussed.

\section{B. Instrument}

The instrument used in this study is the self-made "I Lan County Middle School Student Energy Resource Cognition and Attitude Questionnaire". The questionnaire can be divided into three parts: background variables, an energy resource cognition questionnaire and an energy resource 
attitude questionnaire.

1) The variables considered in this research are described as follows:

a) Independent variable: personal background variables.

b) Dependent variable:

- "Energy resource cognition" score: The energy resource cognition test is an assessment of the energy resource cognition of students who had had energy resource education. High scores demonstrate that such a student displays a better energy conservation and carbon reduction cognition.

- "Energy resources attitude" score: The energy resource attitude test is an assessment of the energy resource cognition of students who had taken energy resource education. High scores demonstrate that such a student exhibited the correct attitude more often.

2) Energy resource cognition questionnaire

The energy resource cognition questionnaire in total had 40 questions, all of which were multiple choice. In order to ensure that the most suitable material and vocabulary were used, 11 middle school Natural and Life Technology teachers were asked to examine the questionnaire and provide opinions regarding any adjustments they thought were needed.

3) The energy resource attitude questionnaire can be broken up into 5 levels:

a) Energy reduction attitude;

b) Green thinking;

c) Life style;

d) Consumer behavior;

e) Personal welfare;

In total, 21 questions were given. A 5 point scale was used and students were asked to respond based on their level of agreement. Selecting "Strongly Agree" was given 5 points. Selecting "Agree" was given 4 points. Selecting "Neutral" was given 3 points. Selecting "Disagree" was given 2 points. Selecting "Strongly Disagree" was given 1 point.

\section{Participants}

The participants consisted of 99 ninth graders from Kai-Syuan Junior High School in 2009. 100\% of the questionnaires were returned and determined suitable for processing.

\section{Procedure and Data Analysis}

This research primarily uses questionnaires to collect data and then the statistical software SPSS Statistics 17.0 to perform statistical analysis of the data. The statistical methods used in this research are described below:

a) Descriptive Statistics: using individual scores, average and standard deviation to describe analyze and discuss the results of the background variables, energy resource cognition questionnaire and energy resource attitude questionnaire.

b) Independent Sample T Test: the independent sample T test is used to separately differentiate the performance of male and female students regarding:

- Energy reduction attitude

- Green thinking

- Life style

- Consumer behavior
- Personal well-being, as well as total energy resource attitude.

c) Paired Sample T Test: the paired sample T test is used to differentiate student performance, before and after the energy resource education was administered, so that the effectiveness of the education could be assessed.

d) Pearson product-moment correlation: The data collected from the questionnaire is by the product-moment correlation method. Whether there is significant correlation between "attitude toward energy" and the attitude toward saving energy, Green ideas, life style, consumer behavior, personal benefit, and overall attitude toward energy in "Attitude toward Energy Questionnaire" is analyzed.

\section{RESUlTS AND DisCUSSION}

\section{A. Student Background Information Analysis}

This research focused on 99 middle school $9^{\text {th }}$ grade students. There were 50 males and 49 females in total.

\section{B. Energy Resource Cognition Questionnaire Analysis}

\section{1) Cognition questionnaire pre-test and post-test score} descriptive statistics

The energy resource questionnaire in total had 40 multiple choice questions, and correct answers were awarded 1 point. The highest pre-test score was 36 points and the lowest pre-test score was 9 points with an average score of 23.94 points. This performance demonstrated that a mid-level score performance already existed before the education was administered. The highest post-education test score was 37 and the lowest was 8 points while the average was 27.98 points (Table I).

TABLE I: DESCRIPTIVE STATISTICS OF COGNITION QUESTIONNAIRE Pre-TEST AND POST-Test SCORES; HS: THE Highest SCORE, LS: THE

\begin{tabular}{|l|c|c|c|c|c|}
\hline \multicolumn{1}{|c|}{ LOWEST SCORE, STD: STANDARD DEVIATION } \\
\hline & HS & LS & Average & STD & $\begin{array}{c}\text { Standard Error } \\
\text { of the } \\
\text { Average }\end{array}$ \\
\hline $\begin{array}{l}\text { Cognition } \\
\text { Pre-Test }\end{array}$ & 36 & 9 & 23.94 & 6.081 & 0.611 \\
\hline $\begin{array}{l}\text { Cognition } \\
\text { Post-Test }\end{array}$ & 37 & 8 & 27.98 & 6.707 & 0.674 \\
\hline
\end{tabular}

TABLE II: PAIRED T TEST ANALYSIS OF THE PRE-AND POST-TEST

\begin{tabular}{|l|l|l|l|l|}
\hline \multicolumn{5}{c}{ COGNITION QUESTIONNAIRE RESULTS } \\
\hline Question \# & Average & STD & $T$ value & $\begin{array}{c}\text { Significance } \\
\text { (two tailed) }\end{array}$ \\
\hline $\begin{array}{l}\text { Post 1 - } \\
\text { Pre 1 }\end{array}$ & -0.020 & 0.639 & -0.315 & 0.754 \\
\hline $\begin{array}{l}\text { Post 2 - } \\
\text { Pre 2 }\end{array}$ & 0.131 & 0.709 & 1.842 & 0.068 \\
\hline $\begin{array}{l}\text { Post 3 - } \\
\text { Pre 3 }\end{array}$ & 0.030 & 0.579 & 0.520 & 0.604 \\
\hline $\begin{array}{l}\text { Post 4 - } \\
\text { Pre 4 }\end{array}$ & 0.091 & 0.591 & 1.532 & 0.129 \\
\hline $\begin{array}{l}\text { Post 5 - } \\
\text { Pre 5 }\end{array}$ & 0.030 & 0.483 & 0.624 & 0.534 \\
\hline $\begin{array}{l}\text { Post 6 - } \\
\text { Pre 6 }\end{array}$ & 0.182 & 0.413 & $4.379 * * *$ & 0.000 \\
\hline $\begin{array}{l}\text { Post 7 - } \\
\text { Pre 7 }\end{array}$ & 0.101 & 0.662 & 1.517 & 0.132 \\
\hline
\end{tabular}




\begin{tabular}{|c|c|c|c|c|}
\hline $\begin{array}{l}\text { Post } 8 \text { - } \\
\text { Pre } 8\end{array}$ & 0.172 & 0.640 & $2.672^{* *}$ & 0.009 \\
\hline $\begin{array}{l}\text { Post } 9 \text { - } \\
\text { Pre } 9\end{array}$ & 0.040 & 0.493 & 0.815 & 0.417 \\
\hline $\begin{array}{l}\text { Post } 10- \\
\text { Pre } 10\end{array}$ & 0.222 & 0.663 & $3.334 * *$ & 0.001 \\
\hline $\begin{array}{l}\text { Post } 11 \text { - } \\
\text { Pre } 11\end{array}$ & 0.030 & 0.415 & 0.726 & 0.470 \\
\hline $\begin{array}{l}\text { Post 13 - } \\
\text { Pre 13 }\end{array}$ & 0.000 & 0.535 & 0.000 & 1.000 \\
\hline $\begin{array}{l}\text { Post } 14 \text { - } \\
\text { Pre } 14\end{array}$ & 0.141 & 0.700 & $2.010^{*}$ & 0.047 \\
\hline $\begin{array}{l}\text { Post } 15- \\
\text { Pre } 15\end{array}$ & 0.455 & 0.627 & $7.211 * * *$ & 0.000 \\
\hline $\begin{array}{l}\text { Post } 16- \\
\text { Pre } 16\end{array}$ & 0.010 & 0.364 & 0.276 & 0.783 \\
\hline $\begin{array}{l}\text { Post } 17- \\
\text { Pre } 17\end{array}$ & 0.010 & 0.678 & 0.148 & 0.882 \\
\hline $\begin{array}{l}\text { Post } 18- \\
\text { Pre } 18\end{array}$ & 0.081 & 0.665 & 1.209 & 0.230 \\
\hline $\begin{array}{l}\text { Post } 19- \\
\text { Pre } 19\end{array}$ & 0.051 & 0.612 & 0.821 & 0.414 \\
\hline $\begin{array}{l}\text { Post } 20- \\
\text { Pre } 20\end{array}$ & 0.051 & 0.361 & 1.393 & 0.167 \\
\hline $\begin{array}{l}\text { Post } 21 \text { - } \\
\text { Pre } 21\end{array}$ & 0.162 & 0.634 & $2.536^{*}$ & 0.013 \\
\hline $\begin{array}{l}\text { Post 22 - } \\
\text { Pre 22 }\end{array}$ & 0.121 & 0.520 & $2.317^{*}$ & 0.023 \\
\hline $\begin{array}{l}\text { Post } 23 \text { - } \\
\text { Pre } 23\end{array}$ & 0.515 & 0.578 & $8.870 * * *$ & 0.000 \\
\hline $\begin{array}{l}\text { Post } 24 \text { - } \\
\text { Pre } 24\end{array}$ & 0.061 & 0.586 & 1.029 & 0.306 \\
\hline $\begin{array}{l}\text { Post } 25 \text { - } \\
\text { Pre } 25\end{array}$ & 0.010 & 0.440 & 0.228 & 0.820 \\
\hline $\begin{array}{l}\text { Post 26- } \\
\text { Pre 26 }\end{array}$ & 0.061 & 0.620 & 0.973 & 0.333 \\
\hline $\begin{array}{l}\text { Post 27 - } \\
\text { Pre } 27\end{array}$ & 0.111 & 0.426 & $2.596^{*}$ & 0.011 \\
\hline $\begin{array}{l}\text { Post } 28- \\
\text { Pre } 28\end{array}$ & 0.030 & 0.630 & 0.479 & 0.633 \\
\hline $\begin{array}{l}\text { Post } 29- \\
\text { Pre } 29\end{array}$ & 0.071 & 0.732 & 0.961 & 0.339 \\
\hline $\begin{array}{l}\text { Post } 30- \\
\text { Pre } 30\end{array}$ & 0.091 & 0.624 & 1.449 & 0.150 \\
\hline $\begin{array}{l}\text { Post } 31 \text { - } \\
\text { Pre } 31\end{array}$ & 0.040 & 0.653 & 0.615 & 0.540 \\
\hline $\begin{array}{l}\text { Post } 32- \\
\text { Pre } 32\end{array}$ & 0.141 & 0.729 & 1.931 & 0.056 \\
\hline $\begin{array}{l}\text { Post } 33- \\
\text { Pre } 33\end{array}$ & 0.141 & 0.670 & $2.099 *$ & 0.038 \\
\hline $\begin{array}{l}\text { Post } 34 \text { - } \\
\text { Pre } 34\end{array}$ & 0.182 & 0.660 & $2.740^{* *}$ & 0.007 \\
\hline $\begin{array}{l}\text { Post } 35- \\
\text { Pre } 35\end{array}$ & 0.364 & 0.692 & $5.230 * * *$ & 0.000 \\
\hline $\begin{array}{l}\text { Post } 36- \\
\text { Pre } 36\end{array}$ & 0.424 & 0.671 & $6.287 * * *$ & 0.000 \\
\hline $\begin{array}{l}\text { Post } 37 \text { - } \\
\text { Pre } 37\end{array}$ & -0.131 & 0.565 & $-2.312^{*}$ & 0.023 \\
\hline $\begin{array}{l}\text { Post } 38- \\
\text { Pre } 38\end{array}$ & -0.212 & 0.435 & $-4.852 * * *$ & 0.000 \\
\hline $\begin{array}{l}\text { Post } 39- \\
\text { Pre } 39\end{array}$ & 0.010 & 0.175 & 0.575 & 0.566 \\
\hline $\begin{array}{l}\text { Post } 40- \\
\text { Pre } 40\end{array}$ & 0.040 & 0.402 & 1.000 & 0.320 \\
\hline $\begin{array}{l}\text { Cognition Post } \\
\text { Test- Cognition Pre } 4 \\
\text { Test }\end{array}$ & 4.040 & 9.305 & $4.320 * * *$ & 0.000 \\
\hline
\end{tabular}

TABLE III: DESCRIPTIVE STATISTICS OF ENERGY RESOURCE ATTITUDE

\begin{tabular}{|l|l|l|l|l|l|}
\hline \multicolumn{1}{|c|}{} & $\begin{array}{l}\text { Total } \\
\text { Average }\end{array}$ & $\begin{array}{l}\text { Total } \\
\text { STD }\end{array}$ & $\begin{array}{l}\text { Question } \\
\#\end{array}$ & $\begin{array}{l}\text { Average } \\
\text { Score } \\
\text { (per question) }\end{array}$ & Rank \\
\hline $\begin{array}{l}\text { Energy } \\
\text { conservation } \\
\text { attitude }\end{array}$ & 30.38 & 3.410 & 7 & 4.341 & 1 \\
\hline Green thinking & 9.71 & 2.730 & 5 & 1.941 & 4 \\
\hline Life style & 6.98 & 1.953 & 3 & 2.327 & 3 \\
\hline $\begin{array}{l}\text { Consumer } \\
\text { behavior }\end{array}$ & 5.43 & 1.617 & 3 & 1.811 & 5 \\
\hline Personal welfare & 9.05 & 1.380 & 3 & 3.017 & 2 \\
\hline $\begin{array}{l}\text { Overall Energy } \\
\text { Resource Attitude }\end{array}$ & 61.56 & 4.658 & 21 & 2.931 & \\
\hline
\end{tabular}

The pre- and post-test cognition questionnaire results were processed using a paired sample $\mathrm{T}$ test. Overall, student performance improved after education (Table II).

Singular problems

with $6,8,10,14,15,21,22,23,27,33,34,35$ and 36 were discussed in order to assist students in significantly increasing their cognition; the greenhouse effect and substitute energy resources, such as fuel cells, were explained, allowing students to build a knowledge base.

However questions 37 and 38 showed decreased student cognition and have therefore been designated as parts of the curriculum that need to be clarified.

\section{Energy Resource Attitude Questionnaire Analysis}

\section{1) Description statistics of the energy resource attitude questionnaire}

In total there were 21 questions, which were divided into the following five sections: energy conservation attitude, green thinking, life style, consumer behavior, and personal welfare.

Table III shows that energy conservation attitude had the highest score, which demonstrates that students already had conscious approaches toward energy consumption. However, as indicated by their scores, the students were unable to transfer this mindset to their consumer behavior and life style. In order to help students incorporate energy consumption conscious attitudes into their daily lives, teachers will motivate and reward students for their accomplishments.

\section{2) Male and female energy resource attitude} independents sample T test analysis

Overall, males and females both demonstrated capable energy resource attitudes (Table IV).

However on the individual levels of "life style" and "personal welfare," males exhibited more significantly positive attitudes because most females display a stronger desire for physical consumption than males, whose focus is more conceptual.

\section{Pearson Product-moment Correlation: Cognition and Attitudes of Energy Resource}

Pearson Product-moment Correlation Analysis was used to compare post-test cognitive questionnaire results after energy education teaching focusing on an energy reduction attitude 
of green thinking, life style, consumer behavior, and personal welfare. The positive $r$ correlation coefficient shows a positive correlation, while the negative $r$ shows a negative correlation. The magnitude of $\mathrm{r}$ represents the correlation level. This study uses 0.2 and 0.5 as the standard to judge the correlation level. $r>0.5$ shows a highly correlation, $0.2<r<0.5$ shows a moderate correlation, and $r<0.2$ shows a low correlation.

TABLE IV: INDEPENDENT SAMPLE T TEST OF MALE AND FEMALE ON ENERGY RESOURCE ATTITUDE

\begin{tabular}{|c|c|c|c|c|c|c|}
\hline Level & Sex & Sample Size & Ave & STD & $\mathrm{T} \#$ & P\# \\
\hline \multirow{2}{*}{$\begin{array}{l}\text { Energy } \\
\text { conservation } \\
\text { attitude }\end{array}$} & M & 50 & 30.06 & 3.559 & -0.954 & 0.342 \\
\hline & $\mathrm{F}$ & 49 & 30.71 & 3.253 & & \\
\hline \multirow[t]{2}{*}{ Green thinking } & M & 50 & 9.74 & 3.016 & 0.121 & 0.904 \\
\hline & $\mathrm{F}$ & 49 & 9.67 & 2.436 & & \\
\hline \multirow[t]{2}{*}{ Life style } & M & 50 & 7.38 & 2.194 & $2.094 *$ & 0.039 \\
\hline & $\mathrm{F}$ & 49 & 6.57 & 1.594 & & \\
\hline \multirow[t]{2}{*}{$\begin{array}{l}\text { Consumer } \\
\text { behavior }\end{array}$} & M & 50 & 5.44 & 1.752 & 0.035 & 0.972 \\
\hline & $\mathrm{F}$ & 49 & 5.43 & 1.486 & & \\
\hline \multirow[t]{2}{*}{$\begin{array}{l}\text { Personal } \\
\text { well-being }\end{array}$} & M & 50 & 9.34 & 1.319 & $2.146^{*}$ & 0.034 \\
\hline & $\mathrm{F}$ & 49 & 8.76 & 1.392 & & \\
\hline \multirow[t]{2}{*}{$\begin{array}{l}\text { Overall Energy } \\
\text { Resource } \\
\text { Attitude }\end{array}$} & M & 50 & 61.96 & 4.398 & 0.872 & 0.386 \\
\hline & $\mathrm{F}$ & 49 & 61.14 & 4.920 & & \\
\hline
\end{tabular}

Ave: average

TABLE V: PEARSON PRODUCT-MOMENT CORRELATION: COGNITION AND ATTITUdES OF ENERGY RESOURCE

\begin{tabular}{|l|c|c|}
\hline \multicolumn{2}{|c|}{ Cognition Post-Test } \\
\hline $\begin{array}{l}\text { Energy reduction } \\
\text { attitude }\end{array}$ & $\begin{array}{c}\text { Pearson Correlation } \\
\text { Coefficient }\end{array}$ & $\begin{array}{c}\text { Significant } \\
\text { (two-tailed) }\end{array}$ \\
\hline Green thinking & -0.107 & 0.003 \\
\hline Life style & $0.256^{*}$ & 0.290 \\
\hline $\begin{array}{l}\text { Consumerism } \\
\text { behavior }\end{array}$ & -0.096 & 0.010 \\
\hline $\begin{array}{l}\text { Personal } \\
\text { welfare }\end{array}$ & 0.048 & 0.344 \\
\hline Overall energy attitude & $0.244^{*}$ & 0.641 \\
\hline$*: p<0.05 ; * *: p<0.01 ; * * *: p<0.001$ & 0.015 \\
\hline
\end{tabular}

There is positive correlation between the post-test results and their energy reduction attitude, life style, and overall attitude toward energy. As shown in Table V, students with higher energy cognition also have better attitudes toward energy.

\section{CONCLUSION}

In this study, a self-made "Energy Education Promotion Manual" is used to implement cognitive teaching. Participants were given a pre-test before energy education instruction and a post-test after it. Then, any differences in energy cognition and attitude were analyzed.

The performance of the students before and after their education was assessed. Before the energy education, the students achieved an intermediate level of energy resource cognition, getting an average score of 23.94 points, and had increased scores of 27.98 points after it. Using a paired sample $\mathrm{T}$ test, it was found that, after the energy education, the students displayed significant improvement ( $t=4.320 * * *)$. These results show that this Energy Education Promotion Manual can effectively improve students' energy cognition. The effectiveness of this manual was especially significant in the global warming and substitute energy resource sections. Regarding energy resource attitudes, the overall score was at an average level with the energy attitude getting the best score of 4.341 and green thinking, life styles and consumer behavior being below average. It showed that students have already established a right attitude toward energy conservation, but they are unable to apply it in daily life. On the differences between the energy resource attitudes of males and females, males scored significantly higher in the life style and personal welfare categories.

Regarding the correlation analysis on energy cognition and attitude, it is positively related between the attitude on energy conservation, life style, and overall energy attitude and cognition post-test score after energy education. Students with a greater energy cognition have better energy attitude and understanding of energy conservation and are thus more likely to proactive in this field. All findings in this study will be useful to improvement of energy education in high school.

\section{APPENDIX-QUESTIONNAIRE}

Energy Awareness and Attitudes Questionnaire for Middle School Students in Ilan County

Dear all,

The purpose of this academic questionnaire is to collect information about current students' understanding and attitudes towards energy. Your personal information and answers will not be disclosed or shared with any third party, please feel free to answer as honestly as possible. Your answers to this questionnaire mean a great deal of help for the research, thank you very much!

Sincerely, National Ilan University

\section{Descriptions:}

The Questionnaire contains three parts, the first part consists of four questions regarding "personal information"; the second part consists of 40 questions regarding "energy awareness"; the third part consists of 21 questions regarding "energy attitudes".

\section{A. Personal Information}

Please answer each question by putting a check in the box corresponding to the choice you find correct or appropriate.
1) Present Grade
1) 7 th 2) 8 th 3) 9 th
2) Gender
1) $\mathrm{M}$ 2) $\mathrm{F}$

\section{B. Energy Awareness Questionnaire (Multiple Choice Questions; Check 1 out of 4)}




\begin{tabular}{|c|c|c|}
\hline 2. & $($ ( ) & $\begin{array}{l}\text { Which of the following is not a product of photosynthesis? } \\
\text { (A) Water (B) Carbon dioxide (C) Oxygen (D) Glucose. }\end{array}$ \\
\hline 3. & ( ) & $\begin{array}{l}\text { Which of the following gases is not considered to be greenhouse gas? } \\
\text { (A) Water vapor (B) Carbon dioxide (C) Methane (D) Oxygen. }\end{array}$ \\
\hline 4. & ( ) & $\begin{array}{l}\text { Which of the following will cause global warming? } \\
\text { (A) Ozone hole (B) Greenhouse effect (C) Forest plantation (D) The } \\
\text { use of solar energy. }\end{array}$ \\
\hline 5. & $($ ( ) & $\begin{array}{l}\text { Greenhouse gas concentrations in the atmosphere have been climbing since nearly half of the century, how does such phenomenon } \\
\text { affect global environment? } \\
\begin{array}{ll}\text { (A) Dropping of sea levels throughout the world (B) The atmosphere absorbs a larger proportion of terrestrial radiation (C) The risk } \\
\text { of a meteoroid striking the Earth surface is higher } & \text { (D) A substantial increase in UV radiation received by the Earth surface. }\end{array}\end{array}$ \\
\hline 6. & ( ) & $\begin{array}{l}\text { Which energy of wind power is converted to electricity or other types of energy? } \\
\begin{array}{lll}\text { (A) Kinetic energy } & \text { (B) Potential energy } & \text { (C) The chemical energy } \\
\text { (D) An elastic potential energy. } & \end{array}\end{array}$ \\
\hline 7. & ( ) & $\begin{array}{l}\text { Due to which of following factors that an enormous proportion of Kenting's coral reefs was dead? } \\
\begin{array}{ll}\text { (A)Water pollution caused by thermal coal ashes (B)A rise in the water temperature caused by waste heat discharged by nuclear power } \\
\text { plants(C)Radiation contamination caused by nuclear power plants } & \text { (D)Hydraulic shocks caused by hydroelectric power plants. }\end{array}\end{array}$ \\
\hline 8. & $($ ( ) & $\begin{array}{l}\text { At present, what type of power generation does Taiwan uses mainly? } \\
\text { (A) Thermal power generation (B) Nuclear generation (C) Wind power } \\
\text { Generation (D) Hydroelectric generation. }\end{array}$ \\
\hline 9. & ( ) & $\begin{array}{l}\text { Which of the following is a secondary energy? } \\
\text { (A)Solar energy (B) Hydro energy (C) Nuclear energy (D) Electric energy. }\end{array}$ \\
\hline 10. & $($ ( ) & $\begin{array}{l}\text { The most outstanding feature of microbial fuel cell is through which of the following process to generate power via microbes? } \\
\begin{array}{lll}\text { (A) Growth (B) Movement } & \text { (C) Metabolism } & \text { (D) Reproduction }\end{array}\end{array}$ \\
\hline 11. & $($ ) & $\begin{array}{l}\text { Which of the following is correct about descriptions of energy? } \\
\text { (A) Has weight, occupies volume (B) Has weight, occupies no } \\
\text { volume (C) Has no weight, occupies volume (D) Has no weight, occupies no volume. }\end{array}$ \\
\hline 12. & $($ ( ) & $\begin{array}{l}\text { Which of the following is not considered as fossil fuels? } \\
\text { (A) Coal (B) Charcoal } \\
\text { (C) Natural gas (D) Oil }\end{array}$ \\
\hline 13. & ( ) & $\begin{array}{l}\text { What should be done to improve the greenhouse effect? } \\
\text { (A) Purifies water (B) Uses air-conditioner more often (C) Reduces } \\
\text { carbon dioxide (D) Work on soil conservation. }\end{array}$ \\
\hline 14. & $($ ) & $\begin{array}{l}\text { How did the trend of carbon dioxide concentrations in the atmosphere change from } 1600 \text { to } 2000 ? \\
\text { (A)Gradually increased (B) Gradually decreased (C) First increased and then decreased (D) First decreased and then increased. }\end{array}$ \\
\hline 15. & $($ ( ) & $\begin{array}{l}\text { Which of the following is correct regarding the greenhouse effect leading to environmental changes? } \\
\begin{array}{lll}\text { (A)The rise of global temperature is due to the increased } \mathrm{CO}_{2} \text { solely } & \text { (B) The rise of sea levels is caused by the greenhouse effect } \\
\text { (C) The decrease in } \mathrm{O}_{3} \text { content is due to the greenhouse effect } & \text { (D) } \mathrm{CO}_{2} \text { absorbs solar radiation. }\end{array}\end{array}$ \\
\hline 16. & $($ ) & $\begin{array}{l}\text { Through energy conversion, which of the following converts chemical energy into electric energy? } \\
\begin{array}{llll}\text { (A)Battery } & \text { (B)Motor } & \text { (C)Windmill } & \text { (D)Dam. }\end{array}\end{array}$ \\
\hline 17. & ( ) & 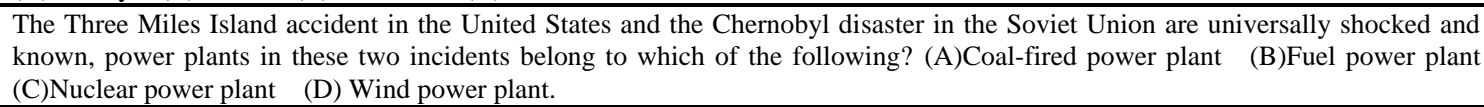 \\
\hline 18. & ( ) & $\begin{array}{l}\text { Which of the following is not correct regarding all types of renewable energy? } \\
\text { (A) Tidal power uses level difference at low tide to drive the turbine and convert the kinetic energy into electricity energy(B) Solar } \\
\text { energy is suitable for year-round sunny regions (C)Biomass energy is referred to plant fermentation converting to alcohol, and then it } \\
\text { is used as fuel (D)Wind power is suitable for all windy regions }\end{array}$ \\
\hline 19. & ( ) & $\begin{array}{l}\text { Compared to proton exchange membrane fuel cell, the direct methanol } \\
\text { fuel cell can also generate which of the following? } \\
\text { (A)Water (B) Carbon dioxide (C) Hydrogen gas (D) Oxygen. }\end{array}$ \\
\hline 20. & ( ) & $\begin{array}{l}\text { Which of the following correctly describes the fuel cell? } \\
\text { (A) The purpose of using proton exchange membrane fuel cell is to } \\
\text { accelerate the efficiency of heat generation (B)Electricity is generated by converting chemical energy to electricity energy (C)Water } \\
\text { will be generated if we use hydrogen gas as the fuel for the cell(D) Direct methanol fuel cell is more beneficial to the environmental } \\
\text { protection than proton exchange membrane cell. }\end{array}$ \\
\hline 21. & $($ ) & $\begin{array}{l}\text { Energy used by human comes directly or indirectly from which of the following? } \\
\text { (A)Green plants (B) Artificial food (C) Geothermal magma (D) Sunlight. }\end{array}$ \\
\hline 22. & $($ ) & $\begin{array}{l}\text { Which of the following reactions will not generate greenhouse gases? } \\
\text { (A) Respiration (B) Photosynthesis (C) Burning of fossil fuels (D) A large number of cattle and sheep rearing. }\end{array}$ \\
\hline 23. & ( ) & $\begin{array}{l}\text { Which of the following is correct about the principle of the greenhouse effect? } \\
\text { (A)The Earth surface absorbs solar radiation (B)The Earth surface absorbs atmosphere radiation (C)The atmosphere absorbs the } \\
\text { Earth surface radiation (D)The atmosphere absorbs the solar radiation. }\end{array}$ \\
\hline 24. & ( ) & $\begin{array}{l}\text { Which of the following is correct regarding the carbon dioxide concentration and the Earth's average temperature? } \\
\text { (A) Concentration rises, the temperature increases (B) Concentration rises, the temperature decreases (C) Concentration rises, but it } \\
\text { does not affect the temperature (D) Concentration decreases, but it does not affect the temperature. }\end{array}$ \\
\hline 25. & ( ) & $\begin{array}{l}\text { What is the main reason the South Pacific island country, Tuvalu is moving its entire population to Australia? } \\
\begin{array}{ll}\text { (A)Severe environmental pollution } & \text { (B)Land subsidence due to excessive pumping of the ground water (C)Overly high climate } \\
\text { (D)The land will be flooded by the rising sea level. }\end{array}\end{array}$ \\
\hline 26. & ( ) & $\begin{array}{l}\text { Based on the basic principle of hydroelectric power generation, what energy is converted to electricity? } \\
\begin{array}{llll}\text { (A)Nuclear energy } & \text { (B)Thermal energy } & \text { (C)Potential energy } & \text { (D)Light energy. }\end{array}\end{array}$ \\
\hline 27. & ( ) & $\begin{array}{l}\text { Many people are opposed of the construction of nuclear power plant, and what kind of pollution are they worried about? } \\
\begin{array}{llll}\text { (A)Thermal pollution } & \text { (B)Noise pollution } & \text { (C)Radiation contamination } & \text { (D)Water pollution. }\end{array}\end{array}$ \\
\hline 28. & ( ) & $\begin{array}{l}\text { How many of the following home appliances, 1) air-conditioner, 2) television, 3) refrigerator, 4) lamp, will generate waste heat? } \\
\begin{array}{llll}\text { (A) } 1 & \text { (B) } 2 & \text { (C) } 3 & \text { (D) } 4\end{array}\end{array}$ \\
\hline 29. & $($ ) & $\begin{array}{l}\text { Compare the internal reaction of proton exchange membrane fuel cell to the combustion of hydrogen gas in air, which of the followi } \\
\text { will be generated commonly? }\end{array}$ \\
\hline
\end{tabular}




\begin{tabular}{|c|c|c|}
\hline & & Carbon dioxide (B) Hydrogen gas (C) Water (D) Hydrogen peroxide. \\
\hline 30. & $($ ( ) & $\begin{array}{l}\text { Which of the following can be used as fuel for proton exchange membrane fuel cells? } \\
\text { (A)Nitrogen (B) Methane (C) Chlorine (D) Helium. }\end{array}$ \\
\hline 31. & ( ) & $\begin{array}{l}\text { Which of the following sequences is correct regarding the transferring between the environment and living things? } \\
\begin{array}{llll}\text { (A)Solar } \quad \text { energy } \rightarrow \text { Producer } \rightarrow \text { Consumer } \rightarrow \text { Decomposer } \rightarrow \text { the } \quad \text { Nature } & \text { (B)Solar } & \text { energy } \rightarrow \text { the } \\
\text { Nature } \rightarrow \text { Consumer } \rightarrow \text { Decomposer } \rightarrow \text { Producer } & \text { (C)Solar } \quad \text { energy } \rightarrow \text { Decomposer } \rightarrow \text { Producer } \rightarrow \text { Consumer } \rightarrow \text { the } & \text { Nature } & \text { (D)The } \\
\text { Nature } \rightarrow \text { Producer } \rightarrow \text { Consumer } \rightarrow \text { Decomposer } \rightarrow \text { Solar energy. } & & & \end{array}\end{array}$ \\
\hline 32. & ( ) & $\begin{array}{l}\text { Which of the following is correct about respiration? } \\
\begin{array}{ll}\text { (A)Plants carry out respiration only at night } & \text { (B)Only animals require respiration } \\
\text { to energespiration is a process of converting nutrients } \\
\text { to (D) No greenhouse gasses will be generated when living things carry out respiration. }\end{array}\end{array}$ \\
\hline 33. & ( ) & $\begin{array}{l}\text { Which of the following greenhouse gasses has the most impact on global greenhouse effect? } \\
\text { (A)Water vapor (B)Carbon dioxide (C)Methane (D)Chlorofluorocarbons }\end{array}$ \\
\hline 34. & $($ ( ) & $\begin{array}{l}\text { Which of the following historical events led to substantial progress in science and civilization, but was a turning point of ecological } \\
\text { destruction at the same time? } \\
\text { (A)Neolithic (B) Renaissance (C) Industrial revolution (D) Era of digital information. }\end{array}$ \\
\hline 35. & $($ ( ) & $\begin{array}{l}\text { Which of the following will not be caused by global warming? } \\
\begin{array}{lll}\text { (A)Living creatures migrate to the poles or higher grounds (B) Increase in the frequency and severity of global floods, droughts and } \\
\text { heat waves } & \text { (C)The disappearance of coastal marshes due to the rise of sea level } & \text { (D)Acid rain }\end{array}\end{array}$ \\
\hline 36. & ( ) & $\begin{array}{l}\text { Regarding the procedures of how a hydroelectric power plant operate: water flows through from higher places to drive the turbine, } \\
\text { then launch the generator, among such form of transformation, which of the following is correct? } \\
\begin{array}{llll}\text { (A)Kinetic energy } \square \text { Potential energy } \square \text { Electic energy } & \text { (B)Potential energy } \square \text { Kinetic energy } \square \text { Electric energy } & \text { (C)Kinetic } \\
\text { energy } \square \text { Thermal energy } \square \text { Electirc energy } & \text { (D)Thermal energy } \square \text { Kinetic energy } \square \text { Electric energy. }\end{array}\end{array}$ \\
\hline 37. & ( ) & $\begin{array}{l}\text { Which of the following is not the reason why people are opposed of the construction of nuclear power plant? } \\
\text { (A)Nuclear waste processing(B)Nuclear radiation safety (C)Nuclear power plant accident safety(D)Causing air pollution }\end{array}$ \\
\hline 38. & ( ) & $\begin{array}{l}\text { Based on the basic principle of thermal power generation, what energy is converted to electricity? } \\
\begin{array}{llll}\text { (A)Potential energy } & \text { (B)Nuclear energy } & \text { (C)Chemical energy } & \text { (D)Light energy }\end{array}\end{array}$ \\
\hline 39. & ( ) & $\begin{array}{l}\text { The reason why greenhouse gases cause greenhouse effect is because these gases absorb which of the following given off by the Earth } \\
\text { surface? } \\
\text { (A) Red (B) IR (C) Violet (D) UV }\end{array}$ \\
\hline 40. & ( ) & 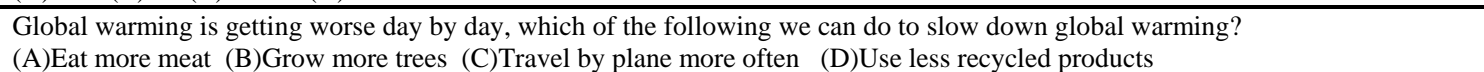 \\
\hline
\end{tabular}

\section{Energy Attitudes Questionnaire (Multiple Choice Questions; Check 1 out of 5)}

\begin{tabular}{|c|c|c|}
\hline I. & Energy conservation attitudes & $\begin{array}{l}\text { 1. Strongly Disagree } \\
\text { 2. Disagree } \\
\text { 3. Neutral } \\
\text { 4. Agree } \\
\text { 5. Strongly Agree }\end{array}$ \\
\hline 1. & $\begin{array}{l}\text { Energy conservation is the responsibility of adults, the children have nothing to do } \\
\text { with it. }\end{array}$ & पमिप्र \\
\hline 2. & $\begin{array}{l}\text { No matter how hard I try to save energy, my endeavor will not be much help to the } \\
\text { overall energy saving. }\end{array}$ & प्वप्र \\
\hline 3. & Taking a bath promotes blood circulation, so we should take a bath more often. & प्मप० \\
\hline 4. & I think it is alright not to turn off the radio if I fall asleep while I listen to the music. & प्वप्र \\
\hline 5. & $\begin{array}{l}\text { The warming phenomenon caused by the greenhouse effect has so far not yet } \\
\text { affected our survival severely, so we do not need to pay attention to it. }\end{array}$ & प्वप्रम \\
\hline 6. & $\begin{array}{l}\text { Feel free to work on energy conservation, but for those who do not care, that is alright } \\
\text { too. }\end{array}$ & प्वप्र \\
\hline 7. & $\begin{array}{l}\text { In order to maintain a quality lifestyle, we do not need to save energy or turn off } \\
\text { lights when leaving. }\end{array}$ & प्वप्र \\
\hline II. & Ideas for green living & \\
\hline 8. & $\begin{array}{l}\text { I think summarizing carbon dioxide emissions throughout the world is a feasible way } \\
\text { to reduce carbon. }\end{array}$ & प्म०० \\
\hline 9. & $\begin{array}{l}\text { We should grow more trees to protect forests if we wish to control the rise of } \\
\text { greenhouse gases. }\end{array}$ & प्मप० \\
\hline 10. & I will get right on it if I know more ways to save energy. & प्मप० \\
\hline 11. & $\begin{array}{l}\text { I think all buildings should improve the ventilation in order to reduce the use of } \\
\text { air-conditioning system. }\end{array}$ & प्पिए \\
\hline 12. & $\begin{array}{l}\text { Energy waste will cause usable energy converting into scattered heat, which does not } \\
\text { go with the concept of environmental protection. }\end{array}$ & प्वप्र \\
\hline III. & Lifestyle & \\
\hline 13. & I used to grow plants to improve the environment and reduce the greenhouse effect. & प्रमप्र \\
\hline 14. & I rather take the stairs than the elevator in school or in the department store. & प्मप० \\
\hline 15. & $\begin{array}{l}\text { We can feed more people by eating vegetables and fruits instead of meat and fish; } \\
\text { hence I am willing to make adjustments of my eating habits. }\end{array}$ & प्पमप \\
\hline IV. & Consumer behaviors & \\
\hline 16. & I will choose to use solar calculator first if it has the same function. & प्वप्रा \\
\hline 17. & I am willing to grow a lot of plants to improve the environment and reduce the & प्मप० \\
\hline
\end{tabular}




\begin{tabular}{|c|c|c|}
\hline & greenhouse effect. & \\
\hline 18. & I will suggest my parents to take the public transportation if they plan to visit Taipei. & 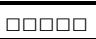 \\
\hline V. & Personal benefits & \\
\hline 19. & Resources consumed by humans will never be reduced. & प्वप्र \\
\hline 20. & $\begin{array}{l}\text { I think the } 4^{\text {th }} \text { nuclear power plant could cause radiation leaks, so I would rather have } \\
\text { restrictions on electricity use in summer than agree on the construction of the } 4^{\text {th }} \\
\text { nuclear power plant. }\end{array}$ & प्वप्र \\
\hline 21. & $\begin{array}{l}\text { Even if scientists prove that global warming is not directly linked with human } \\
\text { activities, I am still willing to use as less energy as I can to reduce carbon dioxide. }\end{array}$ & प्रमप्र \\
\hline
\end{tabular}

\section{Other Suggestions or Comments Regarding Energy:}

Thank you for taking time to answer this questionnaire. If you have any other suggestions or comments, please write them here. Thank you very much for your cooperation.

This is the end of the questionnaire. Thank you for taking time to answer this questionnaire. Please check whether you have completed answering every question. Thank you again for your cooperation.

\section{REFERENCES}

[1] C. J. Tien, "Promotion of today energy education and investigation," Technology and Occupation Education, vol. 40, pp. 28-31, 1997.

[2] J. Y. Wu, R. X. Zhang, M. F. Iv, and P. L. Wang, "Energy conscious of Taiwan student-Elementary school junior high school senior high school," Journal of National Taiwan Normal University, vol. 41, pp. 367-391, 1996.

[3] Y. J. Weng, H. R. Zhang, and Y. C. Weng, “A study on energy attitude toward energy of junior high natural science and living technology teachers," Living Technology Eductaion Journal, vol. 40, no. 1, pp. 32-52, 2007.

[4] R. X. Zhang, "The awareness of energy and the enviornment of hunior high school students in the cities of Taiwan," Journal of National Taiwan Normal University, vol. 41, pp. 475-504, 1996.

[5] J. S. Yarng, "A study on knowledge and attitude toward energy-related issues of high school students in Hsinchu county," Industrial Technology Educational Department, National Kaohsiung Normal University, Master Thesis, 2002.

[6] R. Y. Liu, "A study of knoweldge and attitudes toward energy-related issues about junior high school students," Industrial Technology Educational Department, National Kaohsiung Normal University. Master Thesis, 1994.

[7] Y. R. Chen, "A study of the relationship of energy conservation attitube and home energy use behavior in junior graduates," Industrial
Technology Educational Department, National Changhua Normal University, Master Thesis, 1994.

[8] H. L. Huang, "A study on the knowledge and attitudes toward energy-related issues of high school students in Kaohsiung," Master thesis, Industrial Technology Educational Department, National Kaohsiung Normal University, 1998.

[9] F. J. Lee, "A study on cognition and attitude toward energy-related issues of junier high school teachers and students in Miaoli county," Master thesis, Industrial Technology Educational Department, National Kaohsiung Normal University, 2005.

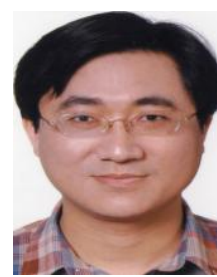

Wang Chin-Tsan was born in 1970 and graduated from the Department of Aeronautics and Astronautics, National Cheng Kung University, Taiwan with BS, MS and $\mathrm{PhD}$ qualifications undertaken between 1992 and 2000. He currently works at National I Lan University, Taiwan. As for his present areas of study, microbial fuel cells, micro fluidic devices and fuel cell flow slabs are the major fields. There are about 60 journal papers, 14 patents and 2 book chapter author contributions that can be attributed to his research performance to date. In addition, Professor Wang was awarded the honor of University Distinguished Professor in 2011 and presented with a National Academic Award in 2013.

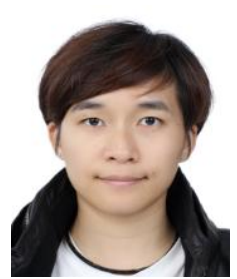

Wu Kai-Ying graduated from the Department of Mechanical and Electro-Mechanical Engineering, National I Lan University, Taiwan in 2014 with an MS qualification. He currently works at Kai-Syuan Junior High School, I-Lan. Taiwan. 